\title{
BIZTONSÁGPOLITIKA
}

\author{
Novák-Varró Virág`
}

\section{Az „ellenálló képesség”, mint a békeépítés eszköze ${ }^{1}$}

DOI 10.17047/HADTUD.2021.31.3.32

Az „ellenálló képesség” békemúveletekben való kifejezett megjelenése az elmúlt néhány évre tehetố csupán, ugyanakkor ez egy jelentős elmozdulást jelez a területen belül. A nemzetközi szervezetek, reagálva a 21. század megváltozott környezetére és az elmúlt évtizedek tapasztalataira egy új koncepcióval álltak elő. Az elképzelés szerint a helyi szereplók, erőforrások, intézmények megerősítése, támogatása révén lehet elérni az önfenntartó békét. Ehhez azonban a nemzetközi szervezeteknek is módosítaniuk kell a békemúveletekben betöltött szerepüket, hogy hatékonyan tudják támogatni a helyi kezdeményezéseket. Ebben az új koncepcióban kap kiemelt szerepet az egyes közösségek, országok ellenálló képessége, mely mintegy sarokkövét képezi az új típusú adaptív békeépítésnek.

KULCSSZAVAK: ellenálló képesség, békeépítés, fenntartható béke, adaptív békeépítés

\section{Resilience as a tool of peacebuilding}

The explicit emergence of resilience in peace operations has been detected only in the past few years, but at the same time it signals a significant shift within the area. Responding to the changed environment of the $21^{\text {st }}$ century and the experience of recent decades, international organizations have come up with a new concept. According to the idea, self-sustaining peace can be achieved by strengthening and supporting local actors, resources and institutions. However, this also requires international organizations to modify their role in peace operations so that they can effectively support local initiatives. In this new concept, the resilience of individual communities and countries has a special role which constitutes the cornerstone of a new type of adaptive peace-building.

KEYWORDS: resilience, peace-building, sustainable peace, adaptive peace-building

^ Nemzeti Közszolgálati Egyetem, Hadtudományi és Honvédtisztképző Kar, Hadtudományi Doktori Iskola, doktorandusz - National University of Public Service, Faculty of Military Science and Officer Training, PhD Candidate; novak-varro.virag@uni-nke.hu; https:// orcid.org/0000-0001-5462-3084

1 A tanulmány az Innovációs és Technológiai Minisztérium ÚNKP-19-3-I-NKE-96 kódszámú Új Nemzeti Kiválóság Programjának szakmai támogatásával készült. 


\section{Bevezetés}

A 21. század konfliktusai jelentős mértékben megváltoztak a megelózó évszázadéhoz képest. Míg a 20. században a fenyegetések döntő többsége az államok felól érkezett, mára a mérleg nyelve átbillent a nem állami szereplók és az államokon belüli konfliktusok felé. Ez a tendencia egyre eróteljesebb kihívás elé állítja az államalapú multilaterális kormányzati rendszert, melyben az egyes nemzetállamoknak egyre sürgetóbbé válik, hogy megtalálják a megfelelő válaszokat az „új típusú” fenyegetésekre. A nemzetállamok a nem állami szereplók által generált kihívásokra adott reakcióiban az államközpontú megközelítés dominál, ugyanakkor a tapasztalatok azt mutatják, hogy ez nem elégséges a konfliktusok hosszú távú rendezéséhez.

A globális rendszer és a konfliktusok jellegének megváltozása elóidézett egy fázisváltást a nemzetközi békeépítés gyakorlatában; a hangsúly kezd átkerülni a liberális idealizmusról és intervencionalizmusról egy sokkal pragmatikusabb megközelítés felé, a stratégiai vagy adaptív békeépítés felé. ${ }^{2}$ Ennek célja a hosszú távú, fenntartható béke elérése egy ember- és közösség-központú megközelítéssel. Ahhoz, hogy ez a megközelítés valóban a tartós békét tudja szolgálni, a konfliktussal terhelt közösség minél behatóbb megismerése, támogatása szükséges. Ennek az egyik legfenntarthatóbb módja, ha az adott közösség ellenálló képességére épít a nemzetközi közösség a beavatkozás során. A tanulmány ez utóbbi mozzanatot, az ellenálló képesség békeépítésben betöltött szerepét kívánja bemutatni. A tanulmány a békemúveletek közül csupán a békeépítéssel foglalkozik, egyrészt mert már a kilencvenes évek óta megfigyelhetô egy hangsúlyeltolódás a békefenntartástól a békeépítés irányába. Másrészt mert a békeépítés folyamatában központi szerepet kap a változások kezelése, támogatása, melyek hozzájárulnak a kitúzött cél, a fenntartható béke eléréséhez.

\section{Az ellenálló képesség fogalma}

Az ellenálló képesség fogalmát célszerú meghatározni, hiszen eredetileg a kifejezés más tudományterületekról szivárgott át, melynek köszönhetően újabb és újabb jelentéstartalommal bóvült ki. A fogalom elsősorban a múszaki tudományok területén vált ismertté, ahol az egyes anyagoknak azon képességét jelentette, hogy azok a mechanikai hatások ellenére is képesek az eredeti alakjukat megórizni vagy visszanyerni. Az ökológiában az ökoszisztéma felépülését vagy adaptációját jelenti egy jelentősebb környezeti változást követóen. A pszichológia a megküzdési mechanizmusokat érti rajta, melynek segítségével az egyén képes a stresszel és más negatív kihívásokkal szembenézni. ${ }^{3}$

A fentiekben vázolt, más tudományterületekról átemelt ellenálló képesség fogalmak is mutatják, hogy habár más aspektusból, de ugyan arról az adottságról van szó: egy adott rendszer megküzdési, adaptációs és reorganizációs képességéról egy nagymértékü kihívással szemben. Ez alapján az ellenálló képesség a társadalom vagy szúkebben

2 Coning 2018, 301.

3 Menkhaus 2013, 2-3. 
értelmezve egy-egy helyi közösség képessége, kapacitása arra, hogy a konfliktusokat megelőzze, kivédje, illetve kezelje azokat. Ebbe beletartoznak az adaptációs és reorganizációs készségek is, melyek révén a megváltozott helyzet, egy krónikus kihívás következtében képesek önmaguk is átalakulni, átszerveződni. ${ }^{4}$

A fogalommal kapcsolatban ugyanakkor fontos megjegyezni, hogy habár a fenti leírás alapján az ellenálló képesség egy közvetlenül vizsgálható jelenségnek túnik, melyet akár empirikus módszerekkel is fel lehetne tárni, azonban ez a gondolkodásmód könnyen félrevezethet. Ahogy számos szerző, ${ }^{5}$ a következókben én is inkább egy lencseként tekintek rá, melyen keresztül vizsgálható az, hogy az egyes szervezetek vagy rendszerek hogyan fognak reagálni egy-egy lehetséges jövóbeni eseményre.

Annak ellenére, hogy készségekról, tulajdonságokról beszélünk egy-egy közösség vagy társadalom ellenálló képessége kapcsán, valójában a statikus kapacitások halmaza helyett sokkal inkább az egyénekben, közösségekben, társadalomban már meglévő, vagy az azokba organikusan beépült folyamatokról, struktúrákról és kapcsolatokról van szó. Ezt a szakirodalom endogén ellenálló képességnek nevezi. Ez a jellemzố nagyban hozzásegíti a béke és a konfliktus ciklusainak folyamatos változásához való alkalmazkodását. Egyúttal azt is jelenti, hogy az idố előre haladtával a kihívásokra adott válaszok még egy közösségben belül is változnak. ${ }^{6}$

\section{Adaptív békeépités és a fenntartható béke koncepciója}

A békeépítés mögötti elméleti hátteret a kezdetektól a liberális béke koncepciója adta, mely szerint a tartós béke elérhetô, amennyiben a konfliktus szereplói meghatározott normákat követnek és bizonyos intézményeket honosítanak meg. Ezek pedig a nyugati világ építókövei; a többpárti demokrácia, a piacgazdaság, az egyéni szabadságjogok és a jogállamiság. ${ }^{7}$ Az elmélet egy olyan modellt állít fel, mely azzal az ígérettel kecsegtet, hogyha a "receptjét” követik, mindig ugyanarra az eredményre vezet; vagyis a tartós béke elérhetố, amennyiben a fenti képlet hiányzó darabkáját megtalálják, és ennek megfelelően kiépítik a szükséges intézményeket. Ez a folyamat láthatóan egy lineáris ok-okozati problémamegoldási modellt használ, azonban az elmúlt évtizedek intervenciói és békeépítési törekvéseinek egy jelentôs része azt mutatja, hogy ez a koncepció nem vezetett mindig sikerre. Különösen az iraki és az afganisztáni beavatkozások nyilvánvaló sikertelensége ${ }^{8}$ mutatta meg szembetúnóen, hogy a liberális intervencionalizmus nem képes megoldani azokat

5$$
6
$$

$$
7
$$

Mind az iraki, mind az afganisztáni beavatkozás instabil rendszereket hagyott maga után, melyek nem voltak képesek a biztonságot garantálni; Irakban teret engedett a szélsóségek megerósödésének, melyból az Iszlám Állam nótte ki magát, Afganisztánt pedig még el sem hagyták a nemzetközi erók, mikor a Tálibán már elfoglalta az ország területének jelentős részét. A szélsóséges fundamentalista és terrorszervezetek megerősödése pedig nemcsak az adott országra jelent fenyegetést, hanem akár a tágabb régió számára is. 
a problémákat, melyek a fent említett országokban a konfliktusok mögött meghúzódnak. Ez pedig elindított egy útkeresést a nemzetközi (nyugati) közösségen belül, melynek eredményeképp egy pragmatikusabb békeépítési modell látszik manifesztálódni. ${ }^{9}$

Az egyik felmerült koncepció az adaptív békeépítés, mely elutasítja a liberális béke elméletét. A megközelítés azt hangsúlyozza, hogy a békeépítés központjába a békefolyamatok támogatását kell helyezni. A tartós (önfenntartó béke) eléréséhez azokat a társadalmi folyamatokat kell elősegíteni, melyek előmozdítják az önszerveződést, és megerôsítik a közösségek és intézmények ellenálló képességét a kívülról vagy belülról érkezó kihívásokkal szemben. Az önszerveződést azonban nem lehet kívülról irányítani, sem kontrolálni, ezeknek a társadalmon belülról kell fakadniuk. ${ }^{10}$ A békeépítés szerepe tehát a belsô folyamatok támogatásává „zsugorodik”; támogatja a társadalmat és ösztönzi a folyamatok elindulását, azok folytatását.

A fenntartható béke (vagy önfenntartó béke) eléréséhez a társadalmaknak szükségük van a saját intézményeik létrehozására, és a „tulajdonosi szemlélet”kialakítására. Ebben a folyamatban a nemzetközi szereplók, legyen szó békeépítésról vagy fejlesztésról, csupán ösztönözni és támogatni tudják a helyi közösségeket. ${ }^{11}$ Ennek a kivitelezése pedig a helyiekkel való szorosabb együttmúködés révén valósulhat meg.

Önmagában az emberek elérése, a helyiekkel való kooperáció nem új koncepció, sót ez évtizedek óta bevett gyakorlat a békemúveletekben. Azonban míg a korábbiakban ezek többsége államközpontú (például a cél az állami autoritás visszaállítása vagy kiterjesztése volt) és múvelet-centrikus célokat túzött ki (a helyiek megnyerése - wining the heats and minds), a stratégiai és fenntartható békeépítés részeként a kooperáció célja, hogy a helyben már meglévő eróforrásokat, eszközöket felfedezzék és megerósítsék. ${ }^{12}$

\section{Változás a békemúveletek terén}

\section{HIPPO jelentés}

Az ENSZ békemúveleteit értékelő magas szintú független testület (High-Level Independent Panel on Peace Operations - HIPPO) már a 2015-ben közzétett jelentésében ${ }^{13}$ beszámolt arról, hogy a békemúveletek nehezen érik el kitúzött céljukat. Ezért, és az új körülményekhez való könnyebb alkalmazkodás, illetve a hatékonyság növelése érdekében javasolja a változtatást. ${ }^{14}$ Ez a változás pedig a fenntartható béke irányába történó elmozdulást és az ehhez szükséges módszerek és kapacitások módosítását, kiegészítését jelöli.

9 Coning 2018, 302-303.

10 Coning 2018, 307.

11 Carvalho, Coning, Connolly, 2014.

12 Mahmoud 2019, 95.

13 United Nations: Report of the High-level Independent Panel on Peace Operations on uniting our strengths for peace: politics, partnership and people. S/2015/446. Forrás: https://peacekeeping.un.org/en /report-of-independent-high-level-panel-peace-operations (Letöltés ideje: 2020. 11. 23.)

14 United Nations: Uniting our Strengths for Peace: Politics, Partnerships and People. Report of the High-Level Independent Panel on United Nations Peace Operations, A/70/95-S/2015/446, 17 June 2015, 9. 
A jelentés fó célként túzi ki az önfenntartó béke elérését. Megállapításai szerint ennek a helyi társadalmi folyamatokból kell kiindulnia, és a helyi közösségek endogén kapacitásán és ellenálló képességén kell alapulnia. ${ }^{15}$ Habár a hangsúly a helyi felelósségvállaláson, a belső intézmények beágyazottságán van, a nemzetközi szereplóknek is fontos feladat jut; a helyi aktorok elérése, az informális viselkedési normák újraéledésének a támogatása révén megerősíteni a lokális törekvéseket. Az ENSZ tehát levonva az eddigi tanulságokat, új megközelítések alkalmazását javasolja, hogy csökkentse a konfliktusba való visszaesés lehetóségét. Ehhez a békemúveleteinek új eszközöket és képességeket kell kifejlesztenie, hogy képesek legyenek ezen új feladatok ellátására.

\section{A NATO reflexiója a változó környezetre}

A jelenlegi gyorsan változó, kiszámíthatatlan biztonsági környezet a NATO-t is arra sarkallta, hogy több figyelmet fordítson a tagállamok civil felkészültségére, mely nélkülözhetetlen a kollektív biztonság fenntartásához. Már a szervezet Alapokmányában is megjelenik az ellenálló képesség elve; a szerződés megköveteli a részes államoktól, hogy "fenntartsák és fejlesszék az egyéni és a kollektív képességeiket a fegyveres támadásokkal szembeni ellenállásra" ${ }^{16}$ Annak ellenére, hogy az elv a NATO történetének legelején már megjelent, csak a 2016. évi varsói csúcson kapott reflektorfényt, immáron reziliencia néven. A csúcstalálkozón a tagállamok vezetói megállapodtak, hogy fokozzák a nemzeti ellenálló képességüket a fenyegetések teljes (hibrid hadviselési) spektrumával szemben. ${ }^{17}$ Habár a megállapodás a szövetség részes államainak képességfejlesztésére (azon belül szúken a védelmi-fókuszú ellenálló képességre) vonatkozik, és számukra állít fel egy minimum standardot, a késóbbi csúcstalálkozók (London 2019, Brüsszel 2021) látókörébe már bekerült a humán biztonság is. A NATO a civilek és gyerekek katonai konfliktusokban való védelmét, az embercsempészek elleni harcot, a szexuális erőszak elleni fellépést a válságövezetekben, valamint a kulturális örökség megóvását is kiemelt feladatának tartja. ${ }^{18}$ A NATO 2030 jelentés tovább erósítette ezt a megközelítést, kibóvítette a nók, biztonság és béke, valamint az éghajlatváltozás területeire, amelynek eredményeképpen a béketámogató múveletekben is érvényesülni fognak a reziliencia elvei. ${ }^{19}$

\section{Az EU átfogó és integrált megközelitése}

2013-ban az Európai Bizottság és a fóképviselő közös közleményt adott ki, amelyben bemutatták az EU külső konfliktusokkal és válságokkal kapcsolatos „átfogó megközelítését" ${ }^{20}$ Ennek a koncepciónak a legnagyobb nóvuma, hogy egyesítette az uniós

15 Coning, 2019, 309-310.

16 The North Atlantic Treaty, 1949.

17 NATO Fact Sheet, Warsaw Summit Key Decisions, February 2017. Forrás: Warsaw Summit Key Decisions

18 Szenes 2021, 236.

19 Meyer-Minnemann 2016.

20 Európai Bizottság, Az Európai Unió Külügyi és Biztonságpolitikai Fóképviselóje. Közös közlemény az Európai Parlamentnek és Tanácsnak. Az EU átfogó megközelítése a külső konfliktusok és válságok tekintetében. Brüsszel, 2013.12.11. elérhető: https://eur-lex.europa.eu/legal-content/HU/TXT/PDF /?uri=CELEX:52013JC0030\&from =en (Letöltés ideje: 2021. 11. 20.) 
eszközök és források felhasználását, és megkövetelte az uniós szintú szereplók és a tagállamok megosztott felelősségét. A helyi felelősségvállalást az EU válságreakciójának egyik fó tételeként azonosítva a közös közlemény a felülról lefelé irányuló megközelítésról az alulról felfelé építkező politikai megközelítésre való elmozdulást jelentette. ${ }^{21}$ 2016-tól az Európai Unió Globális Stratégiájában már egy másik kifejezés, az „integrált megközelítés” jelenik meg. A külsó konfliktusokkal és válságokkal kapcsolatos koherenseb és átfogóbb uniós szerepvállalás keretét adja meg az új stratégia. Magával az ellenálló képességgel egy 2017-es közös nyilatkozatban foglalkoztak. ${ }^{22}$ A reziliencia alatt elsôsorban az államok és a társadalmak ellenálló képességét érti, kiemelve a helyi felelősségvállalás fontosságát. ${ }^{23}$

Mind a három szervezet békemúveletekkel kapcsolatos irányváltása (illetve annak szándéka) egybevág a fent ismertetett adaptív békeépítés koncepciójával.

\section{A reziliencia és a békeépités metszéspontjai}

Az ellenálló képesség alatt tehát a nemzetek, helyi közösségek azon képességét, kapacitását értjük, melynek révén képesek a konfliktusok megelőzésére, kivédésére, a már kialakult problémák kezelésére, illetve az adaptációra és a reorganizációra. Ezen tulajdonságok mind szükségesek, különösen egy mély válságból vagy elhúzódó konfliktusból való kilábaláshoz - ezek pedig mind jellemzőek azon országokra, melyekben békeépítés zajlik. Az ellenálló képesség felóli megközelítést más területeken már korábban is alkalmazták, ${ }_{,}^{24}$ például a humanitárius segítségnyújtásnál, a katasztrófák utáni helyreállításnál, vagy a fejlesztések terén. Ugyanakkor az ezekból levont tapasztalatok nem ültethetók át teljes mértékben a konfliktuskezelés és békeépítés folyamatába. Az alapvetô különbség a kettô között, hogy míg akár a katasztrófák utáni helyreállításnál, akár a humanitárius segítségnyújtásnál a helyi közösségek ellenálló képessége egy külsố, az esetek többségében nem ember által okozott eseményre adott válaszreakció, addig a konfliktusrendezésnél és békeépítésnél már egyértelmúen emberek által generált folyamatokról van szó, ${ }^{25}$ mely egy belsố társadalmi viselkedésben gyökerezik. ${ }^{26}$

A tradicionális békeépítés modelljében kiemelkedő szerepet kap a konfliktus-központú tervezés. Ez azt jelenti, hogy elsôsorban az adott területen jelentkezó problémák felkutatására, azonosítására koncentrál a folyamat, melynek révén fény derül az állam hiányosságaira és a társadalom töredezettségére. Egy társadalom

21 Debuysere \& Blockmans 2019, 245-246.

22 Európai Bizottság, Az Európai Unió Külügyi és Biztonságpolitikai Fóképviselóje. Közös közlemény az Európai Parlamentnek és Tanácsnak. Ellenálló képesség, elrettentés, védelem: az Unió eróteljes kiberbiztonságának kiépítése. Elérhetố: https://eur-lex.europa.eu/legal-content/HU/TXT/PDF /?uri=CELEX:52017JC0450\&from $=$ hu (Letöltés ideje: 2021. 11. 20)

23 European Commission 2017, Joint Communication on „A Strategic Approach to Resilience in the EU's External Action" https://ec.europa.eu/commission/presscorner/detail/en/MEMO_17_1555

(Letöltés ideje: 2021. 11. 20.)

24 Junkos 2018, 559-574.

25 Simpson et al. 2016, 16-17.

26 Novák-Varró 2020, 60. 
akkor tekinthetó törékenynek, amikor az intézményei közül - melyek meghatározzák a politikai, biztonsági, gazdasági és igazságügyi szektorait - néhánynak vagy akár az összesnek gyenge az ellenálló képessége. ${ }^{27} \mathrm{Az}$ állami és a társadalmi hiányosságokra, gyengeségekre alapuló konfliktuselemzések bár elterjedtek a nyugati világban (hiszen magát a konfliktust is egy kerülendô, kiküszöbölendô negatív jelenségként értelmezik), azonban csak a mi? és a miért? kérdésekre tudnak választ adni. Ahhoz, hogy a konfliktus teljes spektrumát fel lehessen tárni, és a fenntartható békére irányuló lépéseket meg lehessen tenni, az ellenálló képesség felóli megközelítést is integrálni kell a vizsgálatba. Ezzel a szemléletmóddal a hol? és hogyan? kérdésekre is megkapjuk a választ, hiszen a reziliencia fóként az egyének, közösségek, társadalmak azon tulajdonságaira, képességeire fókuszál, melyek segítségükre vannak a krízishelyzetekben és az abból való kilábalásban. A két módszer egyesítésével átfogó képet lehet alkotni egy adott konfliktusról, mely hozzájárulhat egy integrált békeépítési és fejlesztési stratégia kialakításához. ${ }^{28}$

Az ellenálló képesség Coning-i megközelítésének gyakorlati alkalmazásakor több ponton tudja segíteni a békeépítést. A reziliencia rávilágít a helyi közösségek és intézmények szisztematikus önsegély-mechanizmusaira, melyek elósegítik a helyi konfliktus-megelózés és az alulról jövő társadalmi és politikai változások kibontakozását. ${ }^{29} \mathrm{~A}$ valódi helyi szereplók kiemelésével pedig hozzájárul a békemúveletek egyik bevett gyakorlatának, a kulcsfontosságú szereplókkel való együttmúködésnek hatékonyabb alkalmazásához.

\section{Az új koncepció kihívásai}

A békeépítés új irányvonalának megjelenésével együtt felmerültek azok a kérdések, amelyek potenciális problémaként jelentkezhetnek a kivitelezés során, érintve mind a helyi, mind a nemzetközi szereplóket.

Az ellenálló képesség-megközelítés a békeépítésben való alkalmazásának ugyanis több korlátozó tényezóje van. Az egyik ilyen tényezó a reziliencia jellegéból fakad, miután az egyszerre lehet pozitív és negatív elôjelú a békeépítés céljait tekintve. ${ }^{30}$ Perspektívától függóen tekinthetünk rá pozitív jellemzóként, mely támogatja a békeépítés célkitúzéseit, de negatívumként is megjelenhet, amennyiben akadályként útját állja a tervek megvalósításának. ${ }^{31}$ Ilyen akadályt jelenthet a helyi informális intézmények támogatása. Annak ellenére, hogy az adaptív békeépítés koncepciójának egyik sarokköve a szubszidiaritás elve alapján a problémák lokális szinten, helyiek általi kezelése, a szakirodalomban "helyi fordulatként" ${ }^{\prime 2}$ megjelenó gyakorlattal kapcsolatban azonban számos kétely felmerül. Habár fontos, hogy a nemzetközi közösség a beavatkozás során támogassa a helyi kezdeményezéseket,

27 Carvalho, Coning, Connolly 2014, 3.

28 Simpson et al. 2016, 9-10.

29 Milliken 2013, 1.

30 Jütersonke, Kartas 2012, 1-8.

31 Novák-Varró 2020, 60.

32 Coning 2019, 311. 
intézményeket, azonban számolni kell azzal, hogy ezek a megoldások nem minden esetben simulnak bele a helyszínen múködő szervezetek agendájába. Előfordulhat, hogy ezek az intézmények a hatalom tradicionális formáiként konzerválják az egyenlótlenség struktúráit; például a nókkel, bizonyos etnikai vagy vallási kisebbségekkel szembeni diszkrimináció valósulhat meg alkalmazásuk esetén, vagy szembe mennek a biztonsági és fejlesztési célokkal. Az ilyen jellegú intézmények gyakorlata nemcsak ellentétes a békeépítés alapelveivel, hanem egyúttal a negatív rezilienciát erôsíti meg a társadalomban, mely gyakorlatilag tovább örökíti a konfliktusokat.

A másik probléma az ellenálló képesség endogén jellegéból fakad. ${ }^{33} \mathrm{~A}$ békeépítésben részt vevő külső aktoroknak figyelembe kell venniük azt a tényt, hogy ók csupán a konfliktusban érintett társadalmak, közösségek vagy államok már meglévő ellenálló képességének támogatására, a folyamatok elósegítésére, rásegítésére hivatottak, nem pedig annak kintról és fentról való létrehozására, felépítésére. ${ }^{34} A$ belső folyamatok, intézmények hatékony múködéséhez pedig elengedhetetlen, hogy a békeépítók ismerjék ezeket az organikusan beépült mechanizmusokat. A helyismeret hiánya, illetve a helyi viszonyok feltérképezésének hiányosságai ugyanakkor általános jelenség a békemúveletekben, mely fóként a beavatkozó felek kapacitáshiányából fakad. A hatékony támogatás megvalósítása érekében tehát fontos, hogy a nemzetközi szereplók megerősítsék ezeket a képességeiket. ${ }^{35}$

Az ellenálló képesség megközelítésének a békemúveletekben való alkalmazásakor kiemelten fontos, hogy a szereplók megértsék és átlássák az adott konfliktus kontextus-specifikus dinamikáit, és hogy a tevékenységeiket az adott közösségben, társadalomban jelen lévő erôsségekre és kapacitásokra építsék. A folyamatban a fenntarthatóság garanciáját az egyes egyének, családok, közösségek, a civil társadalom és a kormányzat közötti párbeszéd adhatja. ${ }^{36}$ Ez egyben a módszer alkalmazásának egyik legnagyobb kihívására is rámutat; megtalálni a megfelelő platformot a kölcsönös párbeszédhez és együttmúködéshez.

\section{Kihívások komplex konfliktuskörnyezetben - Afganisztán}

A következókben az ellenálló képesség békemúveletekben való hasznosíthatóságát szeretném bemutatni Afganisztán példáján keresztül. Afganisztán évtizedek óta törékeny államnak minősül, jelenleg is a világ 9. legsérülékenyebb országa. ${ }^{37} \mathrm{Az}$ afgán társadalmi berendezkedés, bár rendkívül változatos és fragmentált, bizonyos elemei hatékonyan tudják támogatni a közösségek ellenálló képességét a biztonságukat fenyegető kihívásokkal szemben.

Az alternatív társadalomszervezô (törzsi/vallási) intézmények jelentôsége mindig is a zúrzavaros, bizonytalan idókben növekedett meg igazán. Már a nagy játszma idején (1813-1907) is megfigyelhető volt, hogy az európai imperializmussal szemben

33 Novák-Varró 2020, 60-61.

34 Simpson et al. 2016, 18-19.

35 Mahmoud 2019, 95-96.

36 Fostering resilience for sustainable peace, 6.

37 Fragile States Index Annual Report 2020, 7. 
a hagyományos társadalmi formációk ellenálló képessége megmaradt, s ez a jelenkori Afganisztánban is tartja magát. Annak ellenére, hogy Afganisztánban a törzsi rendszer az elmúlt évtizedekben nagy átalakulásokon ment keresztül, és sok tekintetben megkopott, a mögötte meghúzódó rendszer logikája a mai napig meghatározó.

A tradicionális békéltetés rituáléi - akár már intézményesült formában is - az afgán kultúra integráns képét képezik. A legrészletesebben a pastunok becsületkódexe, a Pastunvali tartalmazza az ehhez szükséges eszközöket.

A törzsi szokásjogi eloórásósokon alapuló "kódex" számos megoldási javaslatot kínál a vitás ügyek rendezésére. Ilyen például a tiga, avagy a kő elhelyezésének szokása. ${ }^{38}$ A hagyomány szerint a konfliktusban érintett felek megegyeznek, hogy egy harmadik fél (egy idős vagy egy tiszteletben álló személy) beavatkozzon. Ekkor a feleknek fel kell függeszteniük az egymás közötti harcokat, tartózkodniuk kell a bosszúállástól, annak érdekében, hogy a mediátor egy állandó megoldást találhasson az ügyükben. ${ }^{39} \mathrm{~A}$ közvetítő (salis ul khair) egy, a felek által neutrálisnak és igazságosnak ítélt személy lehet, aki a gyakorlatban általában idôs vallástudós (gyakran a közösség vallási vezetốje) vagy egy kiemelkedó törzsi vezetô. A salis a feleket a kompromisszum felé próbálja terelni, azonban ha ez nem sikerül, akkor az ügy a jirga hatáskörébe kerül. ${ }^{40}$

A jirga szó szerinti jelentése: az a hely, ahol a nyílt beszédnek helye van. A pastun törzsi egyenlőségeszményen alapul, mely lehetôvé teszi minden pastun férfi számára a közösség ügyeinek intézésében való részvételt. A jirga gyakorlatilag a helyi igazságszolgáltatás intézményesült formája, hiszen a közösség legnagyobb tekintéllyel bíró tanácsa, melyben közösen döntenek fontos köz- és magánügyekben. Az ítélkezés a tradicionális törzsi szokásjogi szabályokon alapul, és a három hatalmi ágat egyesíti; vagyis törvényhozói, bírói és végrehajtói hatalommal is bír. Egy kis közösségen belül ez azért szerencsés, mert a helyi szabályok alapján kiszabott ítélet betartását helyileg nyomon is tudják követni. A jirgák azonban nem csak kisebb közösségekben tudnak múködni, egyfajta rendszert alkotva megtalálhatók mindhárom szinten: helyi, regionális és nemzeti szinten is. A jelenkori Afganisztán parlamenti két házának az elnevezésében is megtalálható a jirga szó (wolesi jirga - alsóház, meshrano jirga - felsóház), ahogy 2001 után az ország életének legfontosabb kérdéseit eldöntố ügyekben eljáró szervezet, a loya jirga (nagygyưlés = alkotmányozó nemzetgyứlés) elnevezése is erre a törzsi gyökerekkel rendelkezó intézményre utal.

A fentiekben bemutatott jirga-rendszer a mai napig múködik Afganisztánban. Ennek többek közt az az oka, hogy az állami intézmények (bíróságok, helyi politikai vezetés) sok területen elérhetetlenek, vagy nem épültek ki, vagy nem funkcionálnak. Ahol viszont múködnek, ott az ügyeket nagyon hosszú idő alatt bírálják el, és jelentốs a korrupció lehetôsége is rendszerben. Ezért a helyiek inkább az informális rendszert választják; a helyi jirgához fordulnak ügyeikkel. Ảltalánosságban a jirgák megítélése pozitív, az intézményt megbízhatónak, az ítéleteket igazságosnak tartják, mivel

38 Yunas 2007, 64-70.

39 Semple 2009, 13-14.

40 Uo. 15. 
ezek mind a helyi szokásokon alapulnak. Az ügyeket gyorsan és hatékonyan megoldják, és összességében hatékonynak találják ezt a rendszert. ${ }^{41}$

Ahogy a leírt példákban is látható, annak ellenére, hogy Afganisztánban évtizedek óta háború dúl, a társadalom egyes szintjein megtalálhatók azok az organikusan beépült vitarendezési intézmények, melyek potenciálisan képesek a konfliktusok feloldására. Ami a jirga-rendszerben a jelenlegi afgán államszervezetre nézve kihívást jelent, az az informalitás. A jirgák az állami bíróságok melletti párhuzamos létezése egy kvázi árnyék-igazságszolgáltatási rendszert képez, melynek ráadásul sokkal nagyobb a társadalom általi elfogadottsága. További kockázatot jelent az ítélkezés alapja; a törzsi szokásjog, mely koránt sem mondható egységesnek, és sok tekintetben diszkriminatív is, ezáltal sérül a jogbiztonság és a jogegyenlóség elve is.

A törzsi rendszerben rejlố potenciális kapacitásokat már az afganisztáni rendezésben részt vevő nemzetközi szereplók is felismerték, azonban hatékony alkalmazásuk egy sor akadályba ütközik. Afganisztánban a nemzetközi erók helyi közösségekkel való együttmúködésének leggyakoribb színterei a jirgák/šurák voltak. A Tartományi Ujjáépítési Csoportok múködésének ideje alatt a legtöbb közösséget érintố beavatkozást elóbb megvitatták a helyi gyúlésen, ahol amennyiben megegyezésre került sor, engedélyt kaptak a tervek kivitelezésére. Azonban számos olyan esetról tudni, ahol a helyi jirga jóváhagyása ellenére a közösség részéról ellenállás mutatkozott. Ezek többsége pedig a jirga hiányosságaiból fakad; a tanácskozásokon a társadalom komplett csoportjai - vallási, etnikai kisebbségek, nók, fiatalok stb. nem vehetnek részt, vagy nincs beleszólásuk a döntéshozatalba. Másrészt mivel a szokásjogon és a helyiek normáin alapuló intézményról van szó, a viselkedési normák, hagyományok ismerete elengedhetetlen a hatékony tárgyalás megvalósításához. Ehhez viszont a helyi viszonyok, tradíciók olyan fokú ismerete szükséges, melyek előzetes feltérképezésére a nemzetközi beavatkozó feleknek sok esetben nincs kapacitásuk.

A nemzetközi erók kivonulásával és a Tálibán hatalomátvételével vélhetốen a fent említett, többnyire szokásjogi elemek fognak dominálni, hiszen az általuk bevezetett saría törvénykezés sem a "tiszta” formájában, hanem az afgán (pastun) törzsi hagyományokkal erôsen átitatott változata valósult meg.

\section{Összegzés}

A tanulmányban bemutatott megközelítés az ellenálló képesség elemeinek békeépítésbe való beemelésével egy hibrid módszert vázol fel, melyben a helyi fél nagyobb szerepet vállal a konfliktuskezelésben a tradicionális mechanizmusaira, intézményeire való támaszkodással, míg a békeépítésben részt vevő nemzetközi szereplók csupán a folyamat támogatóiként jelennek meg. Ez ugyanakkor nem egy új koncepció, csupán az eddigi tapasztalatok alapján javaslatot tesz a hangsúlyok áthelyezésére. Megfelelóen kivitelezve hozzájárulhat a konfliktus-megelózés fenntarthatóbb formáihoz és megerősítheti a megelózó békeépítést is. Ezáltal a nemzetközi konfliktuskezelésben

41 Akseer, Rieger 2019, 146-149. 
a reziliencia koncepciója hozzájárulhat egy sokkal proaktívabb, elóre tekintóbb megközelítés kialakításához, melynek révén a kihívások elsó jeleinél jelentkezó problémák átalakításával nagyobb eséllyel lesznek elkerülhetók a mélyebb válságok. A már kialakult és folyamatban lévő konfliktusoknál pedig a hosszú távú, transzformatív megközelítés jelentheti a megoldást, hiszen a sérülékeny társadalmak, államok önszervezôdó kapacitásának támogatása révén a törékeny béke felbomlására is kevesebb lehetőség adódik.

\section{FELHASZNÁLT IRODALOM}

Akseer, Tabasum, Rieger, John (edt.) 2019. Afghanistan in 2019. A Survey of the Afghan People. The Asia Foundation, 2019. Forrás: https://asiafoundation.org/wp-content/uploads/2019/12/2019_Afghan_Survey_Full-Report.pdf (Letöltés ideje: 2020. 11. 25.)

Binnendijk, Hans 2016. "NATO's Future: A Tale of Three Summits." Johns Hopkins SAIS, 2016 November. Forrás: https://archive.transatlanticrelations.org/wp-content/uploads

/2016/11/NATO-binnendijk-november-2016_v1.pdf, (Letöltés ideje: 2020. 11. 23.)

Carvalho, Gustavo de, Coning, Cedric de, Connolly, Lesley 2014. "Creating an Enabling Peacebuilding Environment: How can External Actors Contribute to Resilience?" ACCORD Policy \& Practice Brief, Knowledge for a Durable Peace, 028 Feb. 2014. Forrás:

https://www.accord.org.za/publication/creating-an-enabling-peacebuilding-environment/ (Letöltés ideje: 2020. 11. 23.)

Coning, Cedric de 2018. "Adaptive Peacebuilding." International Affairs 94 (2). https://doi.org/10.1093/ia/iix251

Coning, Cedric de 2019. UN Peace Operations and Changes in the Global Order: Evolution, Adaptation, and Resilience. In Coning, Cedric de, Peter, Mateja: United Nations Peace Operations. Palgrave macmillan. https://doi.org/10.1007/978-3-319-99106-1

Debuysere, Loes, Blockmans, Steven 2019. “Crisis Responders: Comparing Policy Approaches of the EU, the UN, NATO and OSCE with Experiences in the Field." European Foreign Affairs Review 24, no. 3

Donais, Timothy 2013. Peacebuilding and Local Ownership: Post-Conflict Consensus-building.

New York: Routledge.

https://doi.org/10.4324/9780203118078

Európai Bizottság 2013. Az Európai Unió Külügyi és Biztonságpolitikai Fóképviselóje. Közös közlemény az Európai Parlamentnek és Tanácsnak. Az EU átfogó megközelítése a külső konfliktusok és válságok tekintetében. Brüsszel, 2013. 12. 11. Elérhető: https://eur-lex.europa.eu/legal-content/HU/TXT/PDF/?uri=CELEX:52013JC0030\&from=en (Letöltés ideje: 2021. 11. 20.)

Európai Bizottság 2017. Az Európai Unió Külügyi és Biztonságpolitikai Fóképviselője. Közös közlemény az Európai Parlamentnek és Tanácsnak. Ellenálló képesség, elrettentés, védelem: az Unió erôteljes kiberbiztonságának kiépítése. Elérhető:

https://eur-lex.europa.eu/legal-content/HU/TXT/PDF/?uri=CELEX:52017JC0450\&from =hu (Letöltésn ideje: 2021. 11. 20.)

European Commission 2017. Joint Communication on "A Strategic Approach to Resilience in the EU's External Action" Forrás: https://ec.europa.eu/commission/presscorner/detail/en/MEMO_17_1555 (Letöltés ideje: 2021. 11. 20.)

Fostering resilience for sustainable peace. COMECE, Pax Christi International, Justice \& Peace Europe, Mar. 23. 2017, Elérhető:

http://www.juspax-eu.org/en/dokumente/170323-contribution-to-Joint-Communication -on-Resilience.pdf (Letöltés ideje: 2020.11.23.)

Fragile States Index Annual Report 2020. Fund for Peace. 2020, Washington Forrás: https://fundforpeace.org/wp-content/uploads/2020/05/fsi2020-report.pdf (Letöltés ideje: 2020. 11. 24.) 
Juncos, Ana E. 2018. "Resilience in Peacebuilding: Contesting uncertainty, ambiguity, and complexity." Contemporary Security Policy 39 (4): 559-574. Forrás:

https://www.tandfonline.com/doi/full/10.1080/13523260.2018.1491742 (Letöltés ideje: 2020. 11. 24.)

https://doi.org/10.1080/13523260.2018.1491742

Jütersonke, Oliver - Kartas, Moncef 2012. "Resilience: Conceptual Reflections." Geneva Peacebuilding Platform, Brief No. 6. 1-8. Forrás:

https://www.gpplatform.ch/sites/default/files/Brief\%2006\%20-\%20Resilience \%20Conceptual \%20Reflections\%20-\%20Oct.\%202012\%2C\%20with\%20CCDP_2.pdf (Letöltés ideje: 2020. 11. 24.)

Mahmoud, Youssef 2019. People-centred Approach to Peace: at Cross Roads Between Geopolitics, Norms and Practice. In Coning, Cedric de, Peter, Mateja: United Nations Peace Operations.

Palgrave macmillan.

https://doi.org/10.1007/978-3-319-99106-1

Menkhaus, Ken. 2013. "Making Sense of Resilience in Peacebuilding Contexts: Approaches, Applications, Implications." Geneva Peacebuilding Platform, Paper No. 6, 2-3. Forrás: https://www.gpplatform.ch/sites/default/files/PP\% 2006\% 20-\%20Resilience\%20to \%20Transformation\%20-\%20Jan.\%202013_3.pdf (Letöltés ideje: 2020. 11. 23.)

Meyer-Minnemann, Lorenz 2016. "Resilience and Alliance Security: The Warsaw" SAIS, 2016 Forrás: https://archive.transatlanticrelations.org/wp-content/uploads/2016/12/resilience-forward-book -meyer-minnemann-final.pdf (Letöltés ideje: 2020. 11. 23.)

Milliken, Jennifer 2013. "Resilience: From Metaphor to an Action Plan for Use in the Peacebuilding Field." Geneva Peacebuilding Platform, Paper No. 7. Forrás:

https://www.gpplatform.ch/sites/default/files/PP\% 2007\% 20-\%20Resilience-From \%20metaphor\%20to\%20an\%20action\%20plan_1.pdf (Letöltés ideje: 2020. 11. 25.)

NATO Fact Sheet, Warsaw Summit Key Decisions, February 2017. Forrás: https://www.nato.int/nato_static_fl2014/assets/pdf/pdf_2017_02/20170206_1702-factsheet -warsaw-summit-key-en.pdf (Letöltés ideje: 2021. 11. 20 )

Novák-Varró Virág 2020. Az ellenálló képesség szerepe a konfliktus-transzformációban. In: A haza szolgálatában konferenciakötet. Budapest: DOSZ.

Porter, Patric 2009. Military Orientalism. London: Hurst \& Company.

Semple, Michael 2009. Reconciliation in Afghanistan. Washington, DC: United States Institute of Peace Press.

Simpson, Graeme, Makoond, Anupah, Vinck, Patrick,-Pham, Phuong N. 2016. Assessing Resilience for Peace. A Guidance Note. Interpeace Forrás:

http://www.interpeace.org/wp-content/uploads/2016/06/2016-FAR

-Guidace-note-Assesing-Resilience-for-Peace-v7.pdf (Letöltés ideje: 2020. 11. 24.)

Szenes, Zoltán 2021. NATO az új évtizedben.

In Szenes Zoltán (szerk): A mai NATO. A szövetség helyzete és feladatai. Budapest: Zrínyi Kiadó.

The North Atlantic Treaty, Washington D.C. 4. April, 1949. Forrás: https://www.nato.int/cps/en/natolive/official_texts_17120.htm (Letöltés ideje: 2020. 11. 23.)

United Nations: Report of the High-level Independent Panel on Peace Operations on uniting our strengths for peace: politics, partnership and people. S/2015/446. Forrás:

https://peacekeeping.un.org/en/report-of-independent-high-level-panel-peace-operations (Letöltés ideje: 2020.11.23.)

United Nations: Uniting our Strengths for Peace: Politics, Partnerships and People. Report of the High-Level Independent Panel on United Nations Peace Operations, A/70/95-S/2015/446, 17 June 2015.

Using Resilience to Build Peace. Practice Brief: Resilience and Peacebuilding 2016. Interpeace. Frameworks for Assessing Resilience Programme, May 2016 Forrás:

https://www.interpeace.org/wp-content/uploads/2016/06/Practice_Brief-Resilience

_and_Peacebuilding-A4-v3.pdf (Letöltés ideje: 2020. 11. 23.)

Yunas, Syed Fida 2007. Afghanistan A Political History (The Afghans and the Rise and Fall of The Ruling Afghan Dynasties and Rulers). Magánkiadás.

Wallensteen, Peter: Strategic Peacebuilding: Concepts and Challenges In Philipott, Daniel, Powers, Gerard F. 2010. Strategies of Peace. Transforming Conflict in a Violent World.

Oxford: Oxford University Press.

https://doi.org/10.1093/acprof:oso/9780195395914.003.0002 